\title{
In vitro anti-proliferative activity of Argemone gracilenta and identification of some active components
}

\author{
Mario Alberto Leyva-Peralta', Ramón Enrique Robles-Zepeda', Adriana Garibay-Escobar ${ }^{1}$, Eduardo Ruiz-Bustos ${ }^{1}$, \\ Laura Patricia Alvarez-Berber ${ }^{2}$ and Juan Carlos Gálvez-Ruiz ${ }^{1 *}$
}

\begin{abstract}
Background: Cancer is one of the leading causes of death worldwide. Natural products have been regarded as important sources of potential chemotherapeutic agents. In this study, we evaluated the anti-proliferative activity of Argemone gracilenta's methanol extract and its fractions. We identified those compounds of the most active fractions that displayed anti-proliferative activity.

Methods: The anti-proliferative activity on different cancerous cell lines (M12.C3F6, RAW 264.7, HeLa) was evaluated in vitro using the MTT colorimetric method. Identification of the active compounds present in the fractions with the highest activity was achieved by nuclear magnetic resonance (NMR) and gas chromatography-mass spectrometry (GC-MS) analyses.

Results: Both argemonine and berberine alkaloids, isolated from the ethyl acetate fraction, displayed high anti-proliferative activity with $\mathrm{IC}_{50}$ values of $2.8,2.5,12.1$, and $2.7,2.4,79.5 \mathrm{\mu g} / \mathrm{mL}$ on M12.C3F6, RAW 264.7, and HeLa cancerous cell lines, respectively. No activity was shown on the normal L-929 cell line. From the hexane fraction, a mixture of fatty acids and fatty acid esters of 16 or more carbon atoms with anti-proliferative activity was identified, showing a range of $\mathrm{IC}_{50}$ values of 16.8-24.9, 34.1-35.4, and 67.6-91.8 $\mu \mathrm{g} / \mathrm{mL}$ on M12.C3F6, RAW 264.7, and HeLa cancerous cell lines, respectively. On the normal L-929 cell line, this mixture showed a range of $I_{50}$ values of 85.1 to $100 \mu \mathrm{g} / \mathrm{mL}$.
\end{abstract}

Conclusion: This is the first study that relates argemonine, berberine, and a mixture of fatty acids and fatty acid esters with the anti-proliferative activity displayed by Argemone gracilenta.

Keywords: Anti-proliferative activity, Cancer cells, Argemone gracilenta, Alkaloids, Fatty acids, MTT

\section{Background}

Cancer is one of the five leading causes of death, and by 2015 cancer morbidity is expected to climb to nine million people worldwide [1,2]. This growing trend indicates the deficiency in the current cancer therapies, which include surgery, radiotherapy, and chemotherapy $[3,4]$. There is a critical need for anti-cancer agents with higher efficacy, and less side effects that can be acquired at an affordable cost $[2,5,6]$. In this regard, plants represent a viable alternative because they have been valuable

\footnotetext{
* Correspondence: anisolborano@guayacan.uson.mx

'Departamento de Ciencias Químico Biológicas, Universidad de Sonora, Boulevard Luis Encinas y Rosales s/n, Hermosillo, Sonora 83000, Mexico Full list of author information is available at the end of the article
}

resources for traditional remedies since ancient times and continue to be the major source and inspiration for the development of therapeutic agents $[7,8]$. Some phytochemicals have been studied because of their inherent potential to cure diseases, as demonstrated by ancient medicinal practices [7,9]. Over $50 \%$ of anticancer drugs approved by the United States Food and Drug Administration since 1960 have been obtained from natural resources, especially from terrestrial plants [5,7]. Clinically important anticancer agents, such as paciltaxel, camptothecin, and vinblastine, and many other promising anticancer agents, currently under clinical trials, are also plant-derived compounds $[1,10,11]$. Mexico is considered a major supplier of natural resources. Within its great 
diversity of plants it is possible to find the Argemone genus, locally known as "cardo or chicalote" [12]. Species such as Argemone mexicana, Argemone pleiacantha, and Argemone ochroleuca have shown a variety of medicinal properties, such as antibiotic, sedative, analgesic, antimalarial, anti-inflammatory, and anti-tumor effects [12-16].

Argemone gracilenta, another species of the Argemone genus, grows in desert terrains mainly in the state of Arizona, South of the United States, and in the states of Sonora and Baja California Sur, northern Mexico. Previous studies have shown that Argemone gracilenta is relatively rich in alkaloids ( $0.33 \%$ of the dried plant), mainly (-)-argemonine that represents over $90 \%$ of the total plant alkaloids; other alkaloids have also been identified in smaller proportions such as (-)-mutagine, protopin, muramine, and (+)-reticuline [17].

Biological studies on Argemone gracilenta are scarce, and for this reason the aim of this work was to evaluate the anti-proliferative activity of this plant on different cancerous cell lines and to identify the responsible compounds for such activity.

\section{Methods}

\section{General experimental procedures}

Melting points were determined on a Fisher Johns melting point apparatus. The infrared spectra were measured on a Bruker Vector 22 spectrometer. GC-MS spectra were acquired using an Agilent 6890 series GC system and Agilent 5973 mass selective detector, employing a fused-silica column, $30 \mathrm{~m} \times 0.32 \mathrm{~mm}$ HP-5MS (crosslinked 5\% Ph Me silicone, $0.25 \mu \mathrm{m}$ film thickness). The temperature of the column was varied from 40 to $250^{\circ} \mathrm{C}$ with a slope of $10^{\circ} \mathrm{C} / \mathrm{min}$ and a stay of $5 \mathrm{~min}$ at this temperature. All NMR spectra were recorded on a Varian Unity 400 spectrometer at $400 \mathrm{MHz}$ for ${ }^{1} \mathrm{H}$ NMR, and $100 \mathrm{MHz}$ for ${ }^{13} \mathrm{C}$ NMR using DMSO- $d_{6}$ and $\mathrm{CDCl}_{3}$ as solvents. Open column chromatographies were carried out on silica gel 60 (70-230 and 230-400 mesh [Merck]). Preparative TLC was performed on precoated silica gel 60 F254 plates (Merck).

\section{Plant material}

Argemone gracilenta was collected in Guaymas, Sonora $\left(28^{\circ} 05^{\prime} 57^{\prime} \mathrm{N}, 111^{\circ} 03^{\prime} 23^{\prime} \mathrm{W}\right)$, Northwest of Mexico, in May 2011. The plant was taxonomically identified (cata$\log$ No. 08274) by Jesús Sánchez Escalante, taxonomist at the Herbarium of the Universidad de Sonora.

\section{Extraction and fractionation}

The plant was dried at room temperature and homogenized (1400 g) with a Whiley mill (200 mesh). An extract of the homogenized plant was obtained with methanol $(1: 10 \mathrm{w} / \mathrm{v}$; plant/methanol) during 10 days under periodic agitation. The extract was filtered and concentrated to dryness on a rotatory evaporator under reduced pressure at $40^{\circ} \mathrm{C}$. The methanol extract $(130.9 \mathrm{~g})$ was suspended consecutively in $n$-hexane, ethyl acetate, and ethanol $(3 \times 400 \mathrm{~mL}$ for each solvent $)$ with constant agitation for $12 \mathrm{~h}$. The volumes obtained $(1200 \mathrm{~mL})$ were concentrated to dryness under reduced pressure at $40^{\circ} \mathrm{C}$ to yield $26 \mathrm{~g}$ of $n$-hexane, $12.5 \mathrm{~g}$ of EtOAc, and $29.0 \mathrm{~g}$ of $\mathrm{EtOH}$ fractions. The methanol extract and fractions were stored to $-4^{\circ} \mathrm{C}$ in amber glass vials until use [18].

The EtOAc fraction was further chromatographed on a silica gel column (120 g) eluting with $n$-hexane- $\mathrm{CH}_{2} \mathrm{Cl}_{2}$ (100:0 to 0:100), then $\mathrm{CH}_{2} \mathrm{Cl}_{2}-\mathrm{MeOH}$ (100:0 to 0:100) mixtures of increasing polarity to yield 11 fractions.

The FAg-4A fraction (9.7 mg, 0.24\%), eluted with $\mathrm{CH}_{2} \mathrm{Cl}_{2}-\mathrm{MeOH}$ (98:2), was obtained as a yellow-orange oil.

The FAg-5B fraction (450 mg, 11.2\%), eluted with $\mathrm{CH}_{2} \mathrm{Cl}_{2}-\mathrm{MeOH}$ (98:2), was obtained as a colorless oil.

The FAg 7 fraction (20. $5 \mathrm{mg}, 0.51 \%$ ), eluted with $\mathrm{CH}_{2} \mathrm{Cl}_{2}-\mathrm{MeOH}$ (85:15), was subjected to preparative TLC $\left(\mathrm{CH}_{2} \mathrm{Cl}_{2}-\mathrm{MeOH}, 8: 2\right)$ to yield $6.3 \mathrm{mg}$ of argemonine $(\mathrm{Rf}=0.8)$ and $7.9 \mathrm{mg}$ of berberine $(\mathrm{Rf}=0.7)$.

Argemonine. Mp $122.3-123.4^{\circ} \mathrm{C}$ (melting point of reference $\left.147-148^{\circ} \mathrm{C}[19]\right),{ }^{1} \mathrm{H}$ NMR $\left(\mathrm{CDCl}_{3}, 400 \mathrm{MHz}\right), \delta$ ppm; $2.52(\mathrm{~d}, \mathrm{~J}=6.0 \mathrm{~Hz}, \mathrm{H} \alpha-5$ and $\mathrm{H} \alpha-11), 2.45$ (s, N$\mathrm{CH}_{3}$ ), 4.04 (dd, J $=6.61 \mathrm{~Hz}, \mathrm{H}-6$ and $\mathrm{H}-12$ ) 3.58 (s, 3$\mathrm{OCH}_{3}$ and $\left.9-\mathrm{OCH}_{3}\right), 3.66\left(2-\mathrm{OCH}_{3}\right.$ and $\left.8-\mathrm{OCH}_{3}\right), 3.33$ $(\mathrm{d}, \mathrm{J}=5.2 \mathrm{~Hz}, \mathrm{H} \beta-5$ and $\mathrm{H} \beta-11), 6.31$ (s, $\mathrm{H}-1$ and $\mathrm{H}-7$ ), $6.47(\mathrm{H}-4$ and $\mathrm{H}-10) .{ }^{13} \mathrm{C}$ NMR $\left(\mathrm{CDCl}_{3}, 100 \mathrm{MHz}\right), \delta$

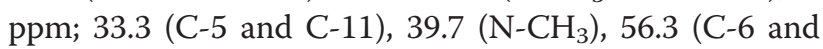
$\mathrm{C}-12), 55.6\left(3-\mathrm{OCH}_{3}\right.$ and $\left.9-\mathrm{OCH}_{3}\right), 55.8\left(2-\mathrm{OCH}_{3}\right.$ and 8- $\left.\mathrm{OCH}_{3}\right), 109.7(\mathrm{C}-4$ and $\mathrm{C}-10), 111.3(\mathrm{C}-1$ and $\mathrm{C}-7)$, 122.5 (C-4a and C-10a), 127.4 (C-1a and C-7a), 147.9 (C-3 and C-9), 148.4 (C21 and C-8).

Berberine. Mp $144.3-146.1^{\circ} \mathrm{C}$ (melting point of reference $146^{\circ} \mathrm{C}$ [19]) ${ }^{1} \mathrm{H}$ NMR $\left(\mathrm{CD}_{3} \mathrm{OD}, 400 \mathrm{MHz}\right), \delta \mathrm{ppm}$; $3.26(\mathrm{t}, \mathrm{J}=5.6 \mathrm{~Hz}, \mathrm{H}-5), 4.12\left(\mathrm{~s}, 9-\mathrm{OCH}_{3}\right), 4.35(\mathrm{~s}, 10-$ $\left.\mathrm{OCH}_{3}\right), 4.95(\mathrm{t}, \mathrm{J}=5.6 \mathrm{~Hz}, \mathrm{H}-6), 6.13\left(\mathrm{~s}, 3-\mathrm{OCH}_{2} \mathrm{O}\right), 6.89$ (s, H-4), 7.45 (s, H-1), 7.95 (d, J = 7.98, H-12), 8.00 (d, J = 7.98, H-11), 8.61 (s, H-13), 9.78 (s, H-8). ${ }^{13} \mathrm{C}$ NMR (CD $\left.\mathrm{CD}_{3} \mathrm{OD}, 100 \mathrm{MHz}\right), \delta \mathrm{ppm}$; $28.2(\mathrm{C}-5), 57.1$ (C-6), 57.6 $\left(9-\mathrm{OCH}_{3}\right), 62.5\left(10-\mathrm{OCH}_{3}\right), 103.6\left(2,3-\mathrm{OCH}_{2} \mathrm{O}\right), 106.5(\mathrm{C}-1)$, 109.3 (C-4), 121.5 (C-13), 121.9 (C-4a), 123.3 (C-12a), 124.5 (C-12), 128 (C-11), 131.9 (C-14a), 135.1 (C-8a), 139.6 (C-14), 145.7 (C-9), 146.4 (C-8), 149.9 (C-3), 152 (C-2 and C-10).

\section{GC-MS analysis of fractions Fag-4A and Fag-5B}

The content of fatty acids and fatty acid esters in fractions FAg-4A and FAg-5B was analyzed by gas chromatography (Agilent 6890) coupled to a quadrupole mass detector in electron impact mode at $70 \mathrm{eV}$ (Agilent $5973 \mathrm{~N}$ ). A solution of $5 \mathrm{mg}$ of each subfraction in $1 \mathrm{~mL}$ of solvent (methanol or dichloromethane) was prepared. Volatile compounds were separated on an HP 5MS 
Table 1 Anti-proliferative activity ( $\mathrm{IC}_{50}$ values) of the methanol extract and fractions of Argemone gracilenta on selected cancer cell lines

\begin{tabular}{|c|c|c|c|c|c|}
\hline \multirow{2}{*}{$\begin{array}{l}\text { Cancer } \\
\text { cell line }\end{array}$} & \multicolumn{5}{|l|}{$I C_{50}(\mu \mathrm{g} / \mathrm{mL})$} \\
\hline & Methanol & Hexane & Ethyl acetate & Ethanol & Residual \\
\hline M12.C3F6 & $46.20 \pm 8.41^{a}$ & $20.40 \pm 2.30^{c}$ & $32.60 \pm 1.10^{b}$ & $21.08 \pm 0.84^{c}$ & $40.60 \pm 10.08^{a}$ \\
\hline RAW 264.7 & $64.45 \pm 8.97 a$ & $36.06 \pm 6.55^{d}$ & $41.27 \pm 4.27^{c}$ & $55.18 \pm 8.80^{b}$ & $64.65 \pm 5.36^{a}$ \\
\hline HeLa & $78.87 \pm 8.52^{b}$ & $70.62 \pm 5.80^{c}$ & $126.28 \pm 5.73^{a}$ & $>200^{*}$ & $>200^{*}$ \\
\hline L-929 & $160.60 \pm 2.15^{b}$ & $131.30 \pm 3.39^{c}$ & $180.61 \pm 4.37 a$ & $>200^{*}$ & $>200^{*}$ \\
\hline
\end{tabular}

Data are shown as the mean \pm SD from three independent repeats after a 48-h exposure to the test extract and fractions. Significant differences ( $p<0.05)$ are indicated by different letters $(\mathrm{a}-\mathrm{d})$. The asterisk $(*)$ represents the maximum concentration tested that did not reach $\mathrm{IC}_{50}$ values.

capillary column (25 m long, $0.2 \mathrm{~mm}$ i.d., $0.3 \mu \mathrm{m}$ film thickness). The oven temperature was set at $40^{\circ} \mathrm{C}$ for $2 \mathrm{~min}$ and then programmed from 40 to $260^{\circ} \mathrm{C}$ at $10^{\circ} \mathrm{C} / \mathrm{min}$, and kept for $20 \mathrm{~min}$ at $260^{\circ} \mathrm{C}$. Mass detector conditions were as follows: interphase temperature was $200^{\circ} \mathrm{C}$ and mass acquisition ranged from 20 to 550 . Temperatures of the injector and detector were set to $250^{\circ} \mathrm{C}$ and $280^{\circ} \mathrm{C}$, respectively. The splitless injection mode was performed with $1 \mu \mathrm{L}$ of the oily extract. The carrier gas was helium at a flow rate of $1 \mathrm{~mL} / \mathrm{min}$. Volatiles were identified by comparing their mass spectra with those of the National Institute of Standards and Technology NIST 1.7 library. Semi-quantitative data were calculated from the GC peak areas without using correction factors and were expressed as relative percentage (peak area \%) of the total volatile constituents identified.

\section{Cell lines and cell culture}

The M12.C3F6 (murine B-cell lymphoma) and RAW 264.7 (macrophage, transformed by Abelson murine leukemia virus) cells lines were kindly provided by Dr. Emil R. Unanue (Department of Pathology and Immunology, Washington University in St. Louis, MO). Cell lines NCTC clone L-929 (normal subcutaneous connective tissue) and HeLa (human cervix carcinoma) were purchased from the American Type Culture Collection (ATCC, Rockville, MD). All cell cultures were carried out in Dulbecco's modified Eagle's medium (DMEM) supplemented with $5 \%$ heat- inactivated fetal calf serum and grown at $37^{\circ} \mathrm{C}$ in an atmosphere of $5 \% \mathrm{CO}_{2}$.

\section{Cell viability assay}

The MTT assay was used to evaluate the antiproliferative activity. It is a colorimetric assay based in the fact that mitochondrial oxidoreductase enzymes are capable of reducing the tetrazolium dye MTT 3-(4,5-dimethylthiazol-2-yl)-2,5-diphenyltetrazolium bromide to its insoluble formazan, which has a purple color. The cellular oxidoreductase enzymes may, under defined conditions, reflect the number of viable cells present. Briefly, cells were seeded in a 96-well plate with DMEM medium (high glucose, supplemented with 5\% FBS) at a density of 10,000 cells/well. Different concentrations of methanol extract and fractions were added followed by $48 \mathrm{~h}$ incubation. All experiments were conducted in parallel with controls (0.06\%-0.5\% DMSO). Ten microliters of 3-(4,5-dimethylthiazol-2-yl)-2,5-diphenyltetrazolium bromide (MTT, $5 \mathrm{mg} / \mathrm{mL}$; Sigma, USA) were added to each well at the end of the treatment period and incubated at $37^{\circ} \mathrm{C}$ for $4 \mathrm{~h}$. Formazan crystals were dissolved with acidic isopropanol, and the plates were read in an ELISA plate reader, using a test wavelength of $570 \mathrm{~nm}$ and a reference wavelength of $630 \mathrm{~nm}$. Plates were normally read within $10 \mathrm{~min}$ after adding isopropanol. The anti-proliferative activity of extracts was reported as $\mathrm{IC}_{50}$ values $\left(\mathrm{IC}_{50}\right.$ value was defined as the concentration of extract that inhibits cell proliferation by $50 \%)[20]$.

\section{Statistical analysis}

All data were expressed as mean \pm SD. Data were subjected to statistical analysis of variance (ANOVA) by comparing means with Tukey test $(\mathrm{p}<0.05)$. IBM $^{\oplus}$ SPSS $^{\bullet} 20$ statistical program was used for all statistical analyses.

\section{Results and discussion}

Anti-proliferative activity assays were performed using the MTT colorimetric assay on three cancerous cell lines (M12. C3F6, RAW 264.7, and HeLa) and a normal cell line (L929) as control. The concentrations used of the methanol

Table 2 Anti-proliferative activity (IC 50 values) of the most active subfractions from the ethyl acetate fraction on selected cancer cell lines

\begin{tabular}{lllll}
\hline \multirow{2}{*}{$\begin{array}{l}\text { Cancer } \\
\text { cell line }\end{array}$} & $\mathbf{I C}_{\mathbf{5 0}}(\boldsymbol{\mu g} / \mathbf{m L})$ & & \\
\cline { 2 - 5 } & $\mathbf{F A g}-\mathbf{4 A}$ & $\mathbf{F A g}-5 B$ & FAg-7A & FAg-7B \\
\hline M12.C3F6 & $16.81 \pm 4.0^{\mathrm{b}}$ & $24.9 \pm 2.2^{\mathrm{a}}$ & $2.8 \pm 0.3^{\mathrm{c}}$ & $2.4 \pm 0.4^{\mathrm{c}}$ \\
RAW 264.7 & $34.1 \pm 5.8^{\mathrm{b}}$ & $35.4 \pm 10.14^{\mathrm{b}}$ & $2.5 \pm 0.5^{\mathrm{b}}$ & $2.7 \pm 0.1^{\mathrm{b}}$ \\
HeLa & $91.8 \pm 7.6^{\mathrm{a}}$ & $67.61 \pm 5.6^{\mathrm{c}}$ & $12.1 \pm 1.7^{\mathrm{d}}$ & $79.5 \pm 11.5^{\mathrm{b}}$ \\
L-929 & $151.7 \pm 1.5^{\mathrm{a}}$ & $85.1 \pm 2.3^{\mathrm{b}}$ & $>100^{*}$ & $>100^{*}$ \\
\hline
\end{tabular}

Data are shown as the mean \pm SD from three independent repeats after a 48-h exposure to the test subfractions. Significant differences $(p<0.05)$ are indicated by different letters (a-d). The asterisk $\left(^{*}\right)$ represents the maximum concentration tested that did not reach $\mathrm{IC}_{50}$ values. 


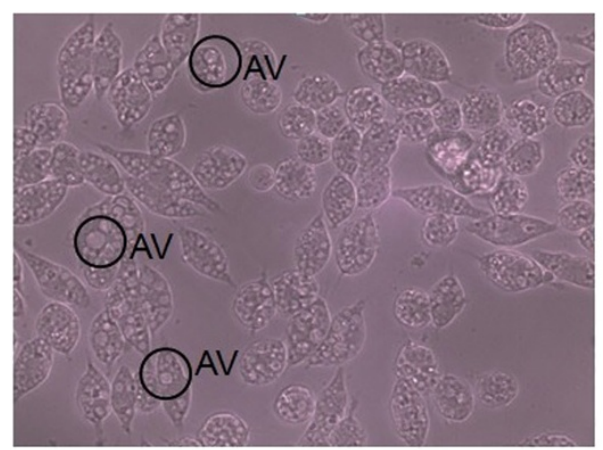

A

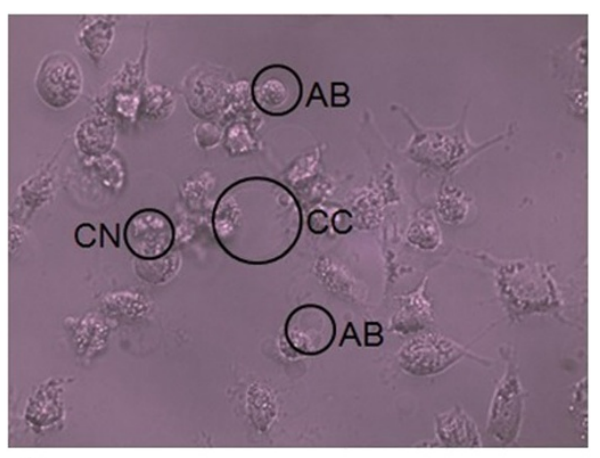

B

Figure 1 Anti-proliferative activity of the Fag-7A (argemonine) fraction on cell lines. A) M12.C3F6 and B) HeLa, at a concentration of $50 \mathrm{\mu g} / \mathrm{mL}$. Observation at $48 \mathrm{~h}$ in inverted microscope. Morphological changes: condensed nucleus (CN), apoptotic bodies (AB), autophagic vacuoles (AV), condensed cytoplasm (CC). All images are magnified at 40x. Images shown are representative of at least four such fields of view per sample and three independent trials.

extract and fractions were from 25 to $200 \mu \mathrm{g} / \mathrm{mL}$, each assay was performed in triplicate.

Table 1 shows the results of the in vitro anti-proliferative activity assays of the Argemone gracilenta's methanol extract and its fractions on different cancerous cell lines. The results are expressed in $\mathrm{IC}_{50}$ values $(\mathrm{mg} / \mathrm{mL}) \pm \mathrm{SD}$. The United States National Cancer Institute (US-NCI) establishes that a crude extract that shows an $\mathrm{IC}_{50}$ value of less than $100 \mu \mathrm{g} / \mathrm{mL}$ is considered active. When the $\mathrm{IC}_{50}$ value is lower than $30 \mu \mathrm{g} / \mathrm{mL}$, the US-NCI considers a crude extract promising for purification and a biological activity study $[3,21]$. In the case of pure compounds, they are considered active when the $\mathrm{IC}_{50}$ values are lower than $4 \mu \mathrm{g} / \mathrm{mL}[22,23]$.

The methanol extract showed activity on the M12. C3F6 cell line with an $\mathrm{IC}_{50}$ value of $46.20 \pm 8.41 \mu \mathrm{g} / \mathrm{mL}$; for RAW 264.7 and HeLa cell lines, the extract showed activity with $\mathrm{IC}_{50}$ values of $64.45 \pm 8.97$ and $78.87 \pm$ $8.52 \mu \mathrm{g} / \mathrm{mL}$, respectively. The methanol extract was not active on the normal cell line L-929 used as control, since it showed an $\mathrm{IC}_{50}$ value $>100 \mu \mathrm{g} / \mathrm{mL}$.

After fractionation of the methanol extract, there was an increment in the activity of some fractions. The ethyl acetate fraction had greater activity, with an increase in the anti-proliferative activity mainly on cell lines RAW 264.7 and M12.C3F6 with $\mathrm{IC}_{50}$ values of $32.60 \pm 1.10$ and $41.27 \pm 4.27 \mu \mathrm{g} / \mathrm{mL}$ respectively, and showing no activity on the normal cell line L-929, with an $\mathrm{IC}_{50}$ value > $100 \mu \mathrm{g} / \mathrm{mL}$.

Chromatographic separation of the ethyl acetate fraction yielded 11 subfractions; of these, fractions Fag-4A, Fag-5B, and the pure compounds argemonine (7A) and berberine (7B) showed anti-proliferative activity on M12. C3F6, RAW 264.7, and HeLa cancer cell lines, and on the L929 control cell line (Table 2). The alkaloid argemonine was the most active, with $\mathrm{IC}_{50}$ values of 2.8 and
$2.5 \mu \mathrm{g} / \mathrm{mL}$ on M12.C3F6 and RAW 264.7 cell lines, respectively (Table 2). Comparing these results with the methanol extract activity indicates that the activity increased, since argemonine was 25-times more active than the methanol extract on the RAW 264.7 cell line. In the HeLa cell line, argemonine showed activity with an $\mathrm{IC}_{50}$ value of $12.1 \mu \mathrm{g} / \mathrm{mL}$, which is 6-times more active than the methanol extract. On the normal cell line L-929, it was not active, indicating that argemonine is selective for cancer cell lines.

Morphological changes in cells caused by the effect of a compound or fraction isolated from a plant can provide information about the cell death mechanism activated in such cells. Various cell death pathways, including apoptosis, autophagy, oncosis, etc., have been proposed. Each of them is characterized by certain morphological changes that can be used to distinguish them through observation

Table 3 Composition of Fag-4A and Fag-5B fractions (GC-MS)

\begin{tabular}{llll}
\hline Fraction & Compound & $\begin{array}{l}\text { Retention } \\
\text { time }(\text { min) }\end{array}$ & Percentage (\%) \\
\hline FAg-4A & $\begin{array}{l}\text { Hexadecanoic acid, } \\
\text { methyl ester } \\
\text { Hexadecanoic acid, }\end{array}$ & 18.62 & 33.39 \\
& $\begin{array}{l}\text { ethyl ester } \\
\text { 7-Octadecenoic acid, } \\
\text { methyl ester }\end{array}$ & 19.28 & 14.98 \\
& $\begin{array}{l}\text { Linoleic acid ethyl ester } \\
\text { FAg-5B }\end{array}$ & 20.34 & 40.83 \\
& $\begin{array}{l}\text { Hexadecanoic acid, } \\
\text { methyl ester }\end{array}$ & 18.62 & 10.78 \\
& $\begin{array}{l}\text { Hexadecanoic acid } \\
\text { 7-Octadecenoic acid, } \\
\text { methyl ester }\end{array}$ & 19.3 & 9.05 \\
9,12-Octadecadienoic acid & 21.11 & 81.63 \\
\hline
\end{tabular}




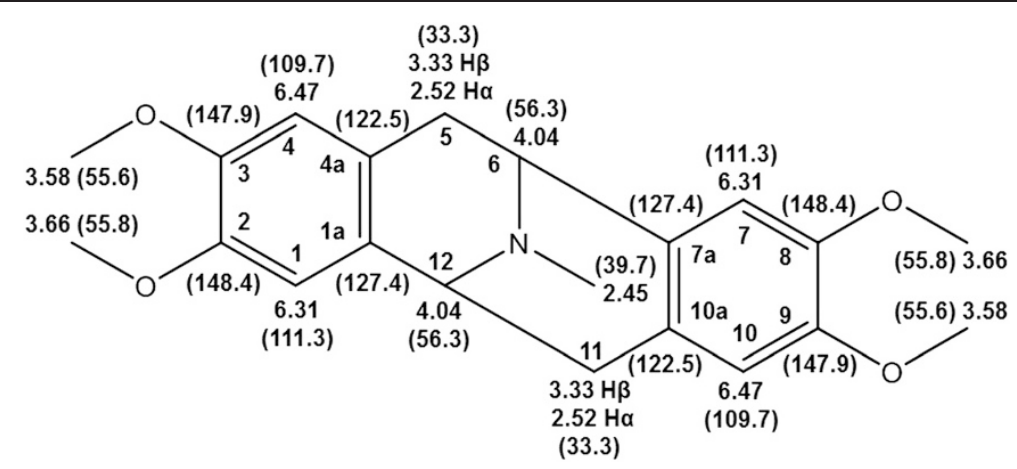

Figure 2 Structure of the main component in Fag-7A fraction, argemonine: ${ }^{1} \mathrm{H}$ NMR $\left({ }^{13} \mathrm{C}\right.$ NMR) data.

under the microscope. Apoptosis is characterized by a nuclear and cytoplasm condensation and cellular fragmentation into membrane-bound fragments (apoptotic bodies). In oncosis, the cell demonstrates swelling, rapid membrane breakdown, swollen nuclei without DNA fragmentation, and organelle swelling. In autophagy, vacuolization (autophagic vacuoles), degradation of cytoplasm contents, and a slight chromatin condensation are observed [24].

The cell lines were observed $48 \mathrm{~h}$ after exposure to argemonine and evidence of two different cell death pathways was found. In the M12.C3F6 cell line (Figure 1A), autophagic vacuoles and degradation of cytoplasm contents, characteristic morphological changes of cell death by autophagy, were observed. In the HeLa cell line (Figure 1B), condensation of the nucleus and cytoplasm, and apoptotic body formation, characteristic morphological changes of cell death by apoptosis, were present.

\section{Structural analysis of the active compounds}

The composition of FAg-4A and FAg-5B fractions were obtained by GC-MS analysis (Table 3). The two fractions are composed of fatty acids of 16 or more carbon atoms. The FAg-4A fraction is a mixture of: 7-octadecanoic acid, methyl ester (40.83\%), hexadecanoic acid, methyl ester (33.39\%), hexadecanoic acid, ethyl ester (14.98\%), and linoleic acid, ethyl ester (10.78\%). The FAg-5B fraction consists of: 9,12-octadecadienoic acid (81.63\%), hexadecanoic acid (9.05\%), 7-octadecenoic acid, methyl ester (8.39\%), and hexadecanoic acid, methyl ester (1.01\%).

The compounds argemonine (7A [25] and berberine (7B [26]) were identified by comparing their spectroscopic data with those previously described in the literature (Figures 2 and 3). The purity of isolated compounds was determined to be above $95 \%$, based on their ${ }^{1} \mathrm{H}$ NMR spectra.

Argemonine is a natural alkaloid from the isoquinoline group, which has been isolated from plants and seeds of several species, including some plants of the genus Argemone, such as A. gracilenta, A. platyceras, A. sanguinea, among others. In addition, it has been found also in species of Buxifolia berberis, Thalictrum revolutum, and T. strictum. The most popular use of argemonine is to

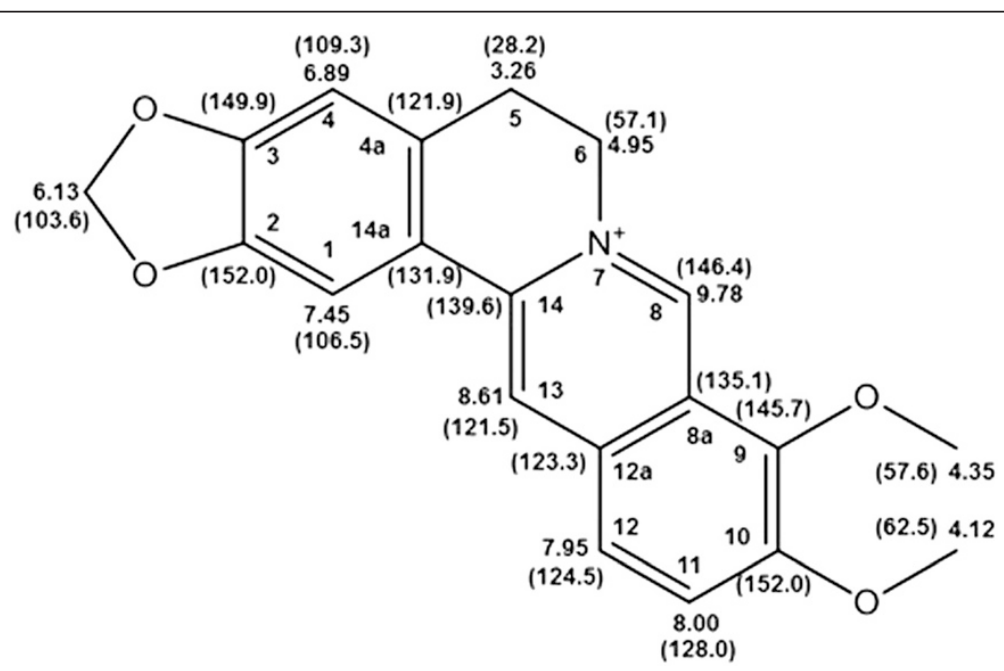

Figure 3 Structure of the main component in Fag-7B fraction, berberine: ${ }^{1} \mathrm{H}$ NMR $\left({ }^{13} \mathrm{C}\right.$ NMR) data. 
control pests in crops, in combination with berberine and ricin, because of its antibacterial, fungicidal, and insecticidal properties [27]. Biological studies of argemonine are scarce, and its biological activities have not been determined yet.

Previous studies have shown that other types of isoquinoline alkaloids, such as sanguinarine and chelerythrine, isolated also from species of the Argemone genus, showed anti-proliferative activity on several cancer cell lines such as HeLa, MCF-7, A-549, and PC-3 [28]. It has been pointed out that sanguinarine induces cell cycle arrest in different phases and apoptosis in a variety of cancer cells [29], besides possessing a wide spectrum of biological activities, such as antimicrobial, antifungal, and antiinflammatory effects.

Studies on berberine have shown its ability to inhibit the growth of various human cancer cell lines. These studies have proven that berberine suppresses cancer cell proliferation by regulating the cell cycle [3,30-32]. In 2011, it was reported that berberine induces cell death by autophagy in hepatocellular carcinoma cell lines HepG2 and MHCC97. Berberine exerts an inhibitory effect on invasion, migration, metastasis, and angiogenesis of cancer cells [33,34]. These results illustrate the potential application of berberine in cancer therapy [3].

Anti-proliferative activity studies have shown that certain fatty acid compounds inhibit the growth of cancer cells. Girao evaluated the effect of 18-carbon fatty acids on the SP210 cell line (mouse myeloma) growth, demonstrating that unsaturated 18 carbon fatty acids exert antiproliferative activity on that cell line, whereas saturated fatty acids (C18.0, stearic acid) show no cell inhibition activity [35]. However, other studies have demonstrated that some fatty acids stimulate the growth of cancer cells. For example, arachidonic acid (C-20:4) stimulates the growth of human prostate cancer cell line, PC-3, by $122 \%$, but these studies also found that fatty acids, such as omega- 3 eicosapentaenoic acid, exert an inhibitory effect on the growth of PC-3 cells [36].

Studies of biological activities and the importance of fatty acids extracted from the Argemone genus are scarce. For this reason, the results regarding the antiproliferative activity of fatty acids, FAG-4A and FAG-5B fractions, could be the starting point for their further study as potential inhibitors of a wide range of human cancer cells, hence, pointing out their relevance in the battle against cancer.

\section{Conclusions}

This study presents the first analysis of the antiproliferative activity of Argemone gracilenta on cancerous cell lines and provides support for the traditional use of this plant against multiple diseases, as well as of other species of the Argemone genus. In addition, two alkaloids, berberine and argemonine, with important anti-poliferative activity were isolated. We present the first analysis of the argemonine alkaloid as an anti-proliferative compound, showing promising results for future studies as a potential anticancer drug. Fatty acids and fatty acids esters of 16 or more carbon atoms with anti-proliferative activity were also identified. This is also the first time that the anti-proliferative activity displayed by plants of the Argemone genus is associated to this type of compounds.

\section{Competing interests \\ The authors declare that they have no competing interests.}

\section{Authors' contributions}

JCGR, MALP, RERZ conceived the study, analyzed data, and drafted the manuscript. MALP, ERB were involved in the generation of organic extracts. AGE, MALP carried out the biological assay. JCGR, MALP, LPAB were involved in isolation and structural analysis of the active compounds. All authors read and approved the final manuscript.

\section{Acknowledgements}

We thank Jesús Sánchez-Escalante from the Herbarium of the University of Sonora for his support on the authentication of the plant. This project was conducted with the economic support from the National Council for Science and Technology of Mexico (CONACYT, Grant 83462).

\section{Author details}

'Departamento de Ciencias Químico Biológicas, Universidad de Sonora, Boulevard Luis Encinas y Rosales s/n, Hermosillo, Sonora 83000, Mexico. ${ }^{2}$ Centro de Investigaciones Químicas, Universidad Autónoma del Estado de Morelos, Av. Universidad No. 1001, Cuernavaca, Morelos 62209, Mexico.

Received: 10 June 2014 Accepted: 19 January 2015

Published online: 05 February 2015

\section{References}

1. Fadeyi SA, Fadeyi OO, Adejumo AA, Okoro C, Myles EL. In vitro anticancer screening of 24 locally used Nigerian medicinal plants. BMC Complement Altern Med. 2013;13(79):1-9.

2. Umthong S, Phuwapraisirisan P, Puthung $S$, Chanchao C. In vitro antiproliferative activity of partially purified Trigona leaviceps propolis from Thailand on human cancer cell lines. BMC Complement Altern Med. 2011;11(37):1-8.

3. Tan W, Lu J, Huang M, Li Y, Chen M, Wu G, et al. Anti-cancer natural products isolated from Chinese medicinal herbs. Chin Med. 2011;6(27):1-15.

4. Alonso-Castro AJ, Villarreal ML, Salazar-Olivo LA, Gomez-Sanchez M, Dominguez F, Garcia-Carranca A. Mexican medicinal plants used for cancer treatment: pharmacological, phytochemical and ethnobotanical studies. J Ethnopharmacol. 2011;133:945-72.

5. Ma X, Wang Z. Anticancer drug discovery in the future: an evolutionary perspective. Drug Discov Today. 2009;14(23/24):1136-42.

6. Gumenyuk VG, Bashmakova NV, Kutovyy SY, Yashchuk VM, Zaika LA. Binding parameter of alkaloids berberine and sanguinarine with DNA. Ukr J Phys. 2011;56(6):524-33.

7. Kim J, Park EJ. Cytotoxic anticancer candidates from natural resources. Curr Med Chem-Anti-cancer. 2002;2(4):485-537.

8. Mann J. Natural products in cancer chemotherapy: past, present and future. Nat Rev Cancer. 2002;2(2):143-8.

9. McChesney JD, Venkataraman SK, Henri JT. Plant natural products: back to the future or into extinction? Phytochemestry. 2007;68:2015-22.

10. Lin YC, Wang CC, Chen IS, Jheng JL, Li JH, Tung CW. TIPdb: a database of anticancer, antiplatelet, and antituberculosis phytochemicals from indigenous plants in Taiwan. Sci World J. 2013;2013:1-4.

11. Cragg GM, Newman DJ. Plants as a source of anti-cancer agents. J Ethnopharmacol. 2005;100:72-9.

12. Sanchez-Mendoza ME, Castillo-Henkel C, Navarrete A. Relaxant action mechanism of berberine identified as the active priciple of Argemone ochroleuca Sweet in guinea-pig tracheal smooth muscle. Pharm Pharmacol. 2008;60:229-36. 
13. Kiranmayi G, Ramakrishnani G, Kothai R, Jaykar B. In vitro anti-cancer of methanolic extract of leaves of Argemone Mexicana Linn. Int J PharmTech Res. 2011;13(3):1329-33.

14. Bhattacharjee I, Chatterjee SK, Chatterjee S, Chandra G. Antibacterial potentiality of Argemone mexicana solvent extracts against some pathogenic bacteria. Mem Inst Oswaldo Cruz. 2006;110(6):645-8.

15. Apu AS, AL-Baizyd AH, Ara F, Bhuyan SH, Matin M, Hossain F. Phytochemical analysis and bioactivities of Argemone mexicana Linn. Leaves PharmacolOnLine. 2012;3:16-23

16. Yuh-Chwen C, Fang-Rong C, Ashraf TK, Pei-Wen H, Yang-Chang W. Cytotoxic benzophenanthridine and benzylisoquinoline alkaloids from Argemone mexicana. Z Naturforsch C. 2003;57:521-6.

17. Stermitz FR, McMurtrey KD. Alkaloids of the Papaveraceae X New alkaloids from Argemone gracilenta Greene. J Org Chem. 1968;34(3):555-9.

18. Ruiz-Bustos E, Velazquez C, Garibay-Escobar A, García Z, Plascencia-Jatomea M, Cortez-Rocha MO, et al. Antibacterial and antifungal activities of some mexican medicinal plants. J Med Food. 2009;12:1398-402.

19. Shakirov R, Telezhenetskaya MV, Bessonova IA, Aripova SF, Israilov IA, Soltankhodzhaev MN, et al. Alkaloids. plants, structure, properties. Chem Nat Compd. 1996;32:216-334

20. Velazquez C, Navarro M, Acosta A, Angulo A, Dominguez Z, Robles R, et al. Antibacterial and free- radical scavenging activities on Sonoran propolis. J Appl Microbiol. 2007;103:1747-56.

21. Suffness M, Pezzuto JM. Assays related to cancer drug discovery. In: Hostettmann K, editor. Methods in Plant Biochemistry. In: Assays for Bioactivity. London: 6: Academic Press; 1990. p. 71-133.

22. Shabana MM, Salama MM, Shahira M, Ismail LR. In Vitro and In Vivo anticancer activity of the fruit peels of Solanum melongena L. against hepatocellular carcinoma. J Carcinog Mutagen. 2013;4(3):1-6.

23. Boik J. Natural Compounds in Cancer Therapy. Minnesota, USA: Oregon Medical Press, Princeton; 2001. p. 25.

24. Fink SL, Cookson BT. Apoptosis, pyroptosis, and necrosis: mechanistic description of dead and dying eukaryotic cells. Infect Immun. 2005;73(4):1907-16.

25. Youte J, Barbier D, Gnecco D, Marazano C. An enantioselective acess to 1-alkalyl-1,2,3,4-tetrahydroisoquinolines. Application to a new synthesis of (-)-argemonine. J Org Chem. 2004;69(8):2737-40.

26. Blasko G, Cordell G, Bhamaraparavati S, Beecher C. Carbon-13 NMR assignments of berberine and sanguinarina. Heterocycles. 1988;27(4):911-6.

27. Fernández, J: Estudio químico biodirigido de la actividad antiasmática de Argemone platyceras. PhD thesis, Universidad Autónoma Metropolitana, Distrito Federal, México; 2005. http://148.206.53.84/tesiuami/UAMI12769.pdf. Accessed August 2014

28. Slaninová I, Pencíková K, Urbanová K, Slanina J, Táburská E. Antitumor activities of sanguinarine and related alkaloids. Phytochemistry Rev. 2013:13:1-9.

29. Jin-Jian L, Jiao-Lin B, Xiu-Ping C, Huang Mand M, Wang Y. Alkaloids isolated from natural herbs as the anticancer agents. Evid Based Complement Alternative Med. 2012;2012:1-12.

30. Mantena SK, Sharma SD, Katiyar SK. Berberine, a natural product induces G1-phase cell cycle arrest and caspase-3-dependent apoptosis in human prostate carcinoma cells. Mol Cancer Ther. 2006;5(2):296-308.

31. Eom KS, Kim HJ, So S, Park R, Kim TY. Berberine-induced apoptosis in human glioblastoma T98G cells is mediated by endoplasmic reticulum stress accompanying reactive oxygen species and mitochondrial dysfunction. Biol Pharm Bull. 2010;3(10):1644-9.

32. Sun $X Y$, Wang $K$, Chen $X$. A systematic review of the anticancer properties of berberine, a natural product from Chinese herbs. Anti-cancer Drugs. 2009;20(9):757-69.

33. Ho Y, Yang J, Li T. Berberine suppresses in vitro migration and invasion of human SCC-4 tongue squamous cancer cells through the inhibitors of FAK, IKK, NF-kB, u-PA and MMP-2 and -9. Cancer Lett. 2009;279(2):155-62.

34. Hamsa T, Kuttan G. Antiangiogenic activity of berberine is mediated through the downregulation of hypoxia-inducible factor-1, VEGF, and proinflammatory mediators. Drug Chem Toxicol. 2012;35(1):57-70.

35. Girao LA, Rock AC, Cantrill RC, Davidson BC. The effect of C18 fatty acids on cancer cells in culture. Anticancer Res. 1986;6(2):241-4.

36. Huges-Fulford $M$, Chen $Y$, Tjandrawinata R. Fatty acid regulates gene expression and growth of human prostate cancer PC-3. Carcinog. 2001;22(5):701-7.

\section{Submit your next manuscript to BioMed Central and take full advantage of:}

- Convenient online submission

- Thorough peer review

- No space constraints or color figure charges

- Immediate publication on acceptance

- Inclusion in PubMed, CAS, Scopus and Google Scholar

- Research which is freely available for redistribution

Submit your manuscript at www.biomedcentral.com/submit 